(C) 2020 by the Arizona Board of Regents on behalf of the University of Arizona. This is an Open Access article, distributed under the terms of the Creative Commons Attribution licence (http://creativecommons. org/licenses/by/4.0/), which permits unrestricted re-use, distribution, and reproduction in any medium, provided the original work is properly cited.

\title{
ESTIMATION OF THE OCCURRENCE TIME OF THE $\Delta^{14} \mathrm{C}$ PEAK IN AD 775 BASED ON THE OXIDATION TIME OF ${ }^{14} \mathrm{C}$ IN THE ATMOSPHERE AND $\Delta^{14} \mathrm{C}$ VALUES IN SUBANNUAL TREE RINGS
}

\author{
Junghun Park $^{1 * \text { (D) }} \cdot$ Jeong-Wook Seo $^{2} \bullet \mathrm{W} \mathrm{Hong}^{1}$ (I) $\bullet$ G Park $^{1} \bullet$ Kilho Sung $^{1} \bullet$ Yong Jin Park $^{1} \bullet$ \\ Yo-Jung $\mathrm{Kim}^{2}$ \\ ${ }^{1}$ Korea Institute of Geoscience and Mineral Resources (KIGAM), 124 Gwahang-no, Yuseong-gu, Daejeon 34132, \\ Korea \\ ${ }^{2}$ Chungbuk National University, Chungdae-ro 1, Seowon-Gu, Cheongju, Chungbuk 28644, Korea
}

\begin{abstract}
The ${ }^{14} \mathrm{C}$ peak in AD 775 (M12) has been measured and confirmed globally in several studies since it was first measured in annual tree rings by Miyake et al. (2012). However, M12 data measurements in early- and latewood are limited. This paper presents the $\Delta^{14} \mathrm{C}$ values in early- and latewood from $\mathrm{AD} 762-776$ Zelkova serrata tree rings from Bangu-dong, Ulsan, South Korea $\left(35^{\circ} 33^{\prime} \mathrm{N}, 129^{\circ} 20^{\prime} \mathrm{E}\right)$. The results indicate no early rise in $\Delta^{14} \mathrm{C}$ values in the latewood of $\mathrm{AD} 774$ in this sample located at mid-latitude. A comparison of the results of this and previous studies suggests latitude dependence (Büntgen et al. 2018); that is, the early rise of $\Delta^{14} \mathrm{C}$ in $\mathrm{AD} 774$ was not observed at mid-latitudes in South Korea but was observed at high latitudes in Finland. The half-oxidation time of ${ }^{14} \mathrm{C}$ was estimated from a detailed analysis of a small bomb peak in AD 1962. Based on the half-oxidation time, the $\Delta^{14} \mathrm{C}$ rise in the latewood, but not in the earlywood, of AD 774 in Finland, and the absence of a $\Delta^{14} \mathrm{C}$ rise in both the early- and latewood of AD 774 in South Korea, the ${ }^{14} \mathrm{C}$ spike was estimated to have been produced from late April to mid-June in AD 774.
\end{abstract}

KEYWORDS: M12, $\mathrm{AD} 775$, occurrence time of M12, oxidation time of $\mathrm{CO}_{2}$.

\section{INTRODUCTION}

Since the discovery of the AD $775{ }^{14} \mathrm{C}$ peak (M12) by Miyake (Miyake et al. 2012), M12 has been confirmed, and its potential causes have been investigated by several groups. The potential causes of M12 include a solar proton event (SPE) (Melott and Thomas 2012; Thomas et al. 2013; Usoskin et al. 2013; Jull et al. 2014; Mekhaldi et al. 2015), supernova (Miyake et al. 2012), gamma ray burst (GRB) (Hambaryan and Neuhäuser 2013; Pavlov et al. 2013), and normal periods of low solar activity (Neuhäuser and Neuhäuser 2015). Alone, none of the abovementioned potential causes is sufficient to explain M12, but an SPE seems to have been a primary cause of M12. If M12 was caused by a supernova, there should be a residual candidate supernova in close proximity to the Earth (Miyake et al. 2012). However, no supporting evidence for such a supernova has been found (Stephenson 2015). Supernovae emit high-energy particles and gamma rays. The high-energy particles from supernovae have an abundant energy distribution. Hence, extended arrival times that span a minimum of at least 10 years should be observed (Gehrels et al. 2003; Dee et al. 2017). However, the M12 peak exhibits a sharp 1-2-year increase. Gamma rays from supernovae and GRBs have a very short duration, which implies that a rapidly rising ${ }^{14} \mathrm{C}$ peak may occur. It has been shown that the M12 concentrations of the cosmogenic isotope ${ }^{10} \mathrm{Be}$ measured in Antarctic ice were too high to have been produced by a GRB (Usoskin et al. 2013). Although the exact cause of M12 is still disputed, an SPE is considered a possible cause due to the ${ }^{10} \mathrm{Be} /{ }^{36} \mathrm{Cl}$ measured in polar ice cores (Mekhaldi et al. 2015). However, more evidence is required to confirm an SPE as the cause of M12. Moreover, the ${ }^{14} \mathrm{C}$ peaks in AD 993/994 (Miyake et al. 2013) and 660 BC (Park et al. 2017) are similar to M12 and may have similar explanations.

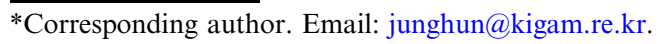




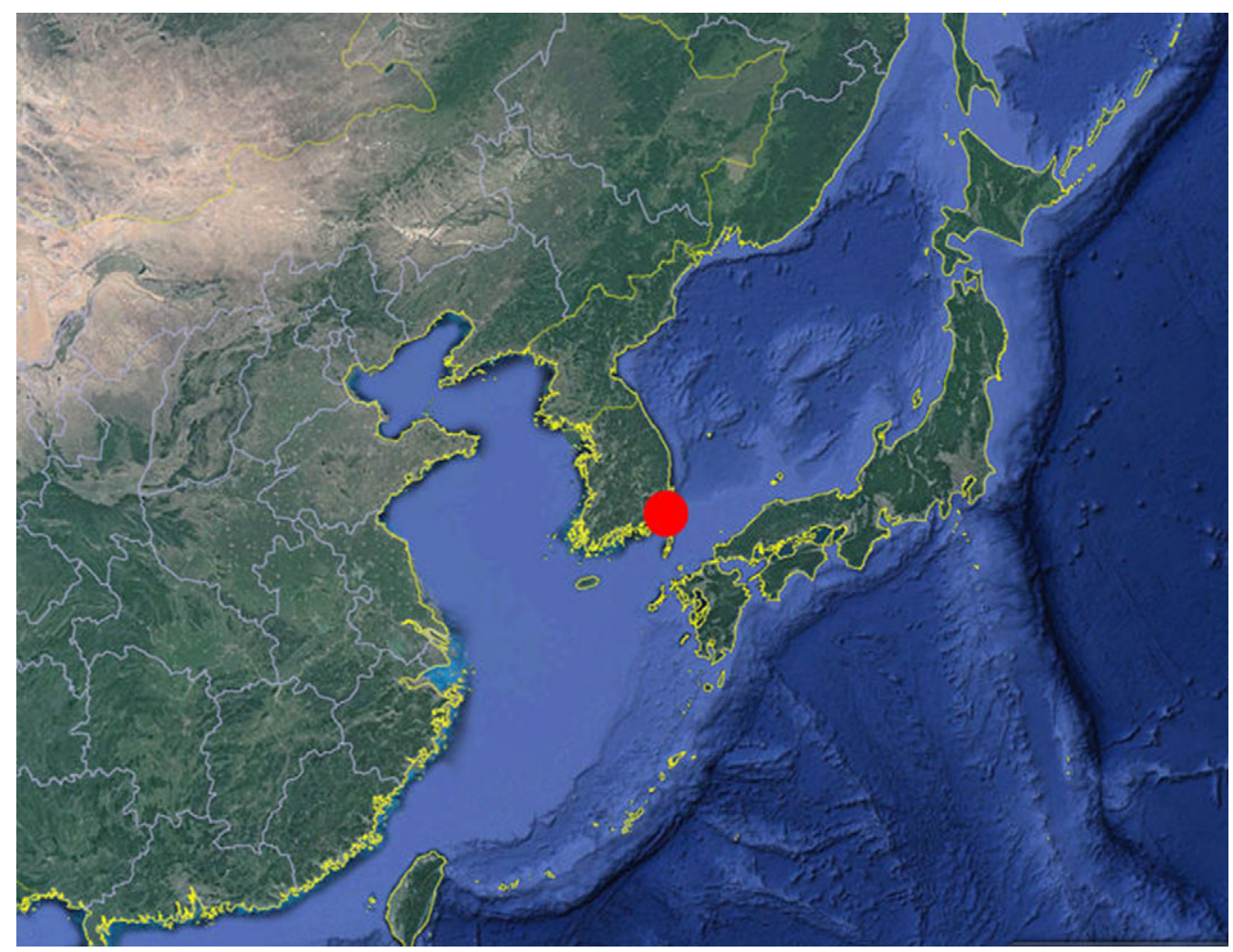

Figure 1 Map of the sampling site (red solid circle; Bangu-dong, Ulsan, Korea, $35^{\circ} 33^{\prime} \mathrm{N}, 129^{\circ} 20^{\prime} \mathrm{E}$ ).

Under the assumption that an abrupt increase in the production of ${ }^{14} \mathrm{C}$ led to $\mathrm{M} 12$, the aim of this study was to estimate the occurrence time of the abrupt increase in ${ }^{14} \mathrm{C}$ production based on a comparison of data measured in South Korea and Finland (Uusitalo et al. 2018). The occurrence time of the ${ }^{14} \mathrm{C}$ spike production estimated by Güttler (Güttler et al. 2015) was between September AD 774 and September AD 775, whereas that obtained by Büntgen (Büntgen et al. 2018) was between June and August of AD 774. These two studies did not include the oxidation time of ${ }^{14} \mathrm{C}$ in their estimations, so the estimated occurrence times of the abrupt increase in ${ }^{14} \mathrm{C}$ production are at least a few months late, as the residence time of ${ }^{14} \mathrm{C}$ ranges from one month to 5 years (Jaffe et al. 1968; Robbins et al. 1968; Weinstock 1969; Weinstock and Niki 1972; Volz et al. 1980; Logan et al. 1981; Brenninkmeijer et al. 1992; Daniel 1999). In this study, we investigated the oxidation time from a detailed analysis of a bomb peak, which differs from the methods used in previous studies. This oxidation time and the early rise in the $\Delta^{14} \mathrm{C}$ values in the latewood of $\mathrm{AD} 774$, one year earlier than the AD 775 timing obtained by other researchers (Uusitalo et al. 2018), was considered to provide an estimate of the occurrence time of the abrupt increase in ${ }^{14} \mathrm{C}$ production.

\section{MATERIALS AND METHODS}

The early- and latewood in tree rings (AD 762-776) of Zelkova serrata C.E. excavated from a burial site at Bangu-dong in Ulsan, South Korea $\left(35^{\circ} 33^{\prime} \mathrm{N}, 129^{\circ} 20^{\prime} \mathrm{E}\right)$ (Figure 1), 


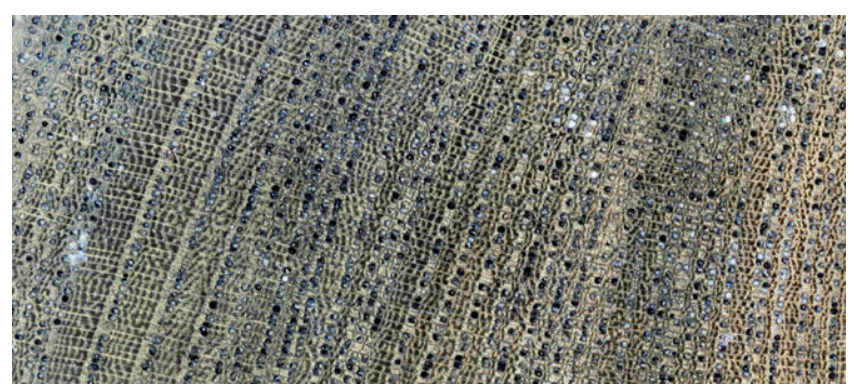

Figure 2 Cross-section scanning image of the experimental archaeological wood (Zelkova serrata).

were prepared at the Tree-Ring Research Center of Chungbuk National University to provide measurement samples for $\Delta^{14} \mathrm{C}$ analysis (Figure 2). This burial site is situated in the region of the Asian monsoon; thus, the tree rings were under the influence of the Asian monsoon.

Previous studies have confirmed that the $\delta^{18} \mathrm{O}$ chronology can be used in cross-dating for other tree species (Li et al. 2015; Seo et al. 2017) and applied to areas situated at a distance of approximately $1000 \mathrm{~km}$ from the origin (Baker et al. 2015). Based on such findings, the Zelkova tree-ring $\delta^{18} \mathrm{O}$ time series was compared with the Japanese master $\delta^{18} \mathrm{O}$ chronology, which is the mean chronology of three local $\delta^{18} \mathrm{O}$ chronologies from Aomori (Thujopsis dolabrata var. hondae), Akita (Crypomeria Japonica), and Niigata (Zelkova serrata), located in northwest Japan. The Japanese master $\delta^{18} \mathrm{O}$ chronology ranged from AD 502 to 1595 . The Zelkova tree-ring $\delta^{18} \mathrm{O}$ time series was cross-dated with the Japanese master $\delta^{18} \mathrm{O}$ chronology and completely overlapped with the Japanese master $\delta^{18} \mathrm{O}$ chronology, so that the first and last tree rings were successfully dated in AD 752 and 861, respectively (Choi 2019). The dating results were decided based on the t-value (4.4), G-value (58\%), and correlation coefficients $(\mathrm{r}=0.40, \mathrm{p}<0.001)$ and also the synchronization strength between the Zelkova tree-ring $\delta^{18} \mathrm{O}$ time series and Japanese master $\delta^{18} \mathrm{O}$ chronology.

Zelkova serrata is a genus comprising six species of deciduous trees in the elm family Ulmaceae, which is native to southern Europe and southwest and eastern Asia (Bétrisey et al. 2018; Wikipedia). Early- and latewood from AD 762-776 were treated using the $\alpha$-cellulose extraction method (Hua et al. 2004). This method removes unwanted mobile materials such as gums, resins, fats, and waxes, leaving the $\alpha$-cellulose behind. The samples were heated at $80^{\circ} \mathrm{C}$ for $6 \mathrm{hr}$ in a mixed solution of $120 \mathrm{~mL}$ cyclohexane and $60 \mathrm{~mL}$ ethanol. The remains were repeatedly rinsed with ethanol and de-ionized water. Thereafter, the samples were treated with $150 \mathrm{mg} \mathrm{NaClO}_{2}$ and $1 \mathrm{M} \mathrm{HCl}$ at $100^{\circ} \mathrm{C}$ for $1-2 \mathrm{hr}$. The samples were then treated in a $12 \% \mathrm{NaOH}$ solution with nitrogen gas bubbling at $60^{\circ} \mathrm{C}$. Finally, the samples were neutralized with a $2 \mathrm{M} \mathrm{HCl}$ solution for $30 \mathrm{~min}$ and dried in an oven at $40^{\circ} \mathrm{C}$. An elemental analyzer (EA) was used for combustion to produce $\mathrm{CO}_{2}$, which was then reduced to graphite. The ${ }^{14} \mathrm{C} /{ }^{12} \mathrm{C}$ and ${ }^{13} \mathrm{C} /{ }^{12} \mathrm{C}$ ratios of the samples were measured using the $1 \mathrm{MV}$ accelerator mass spectrometer (AMS) at the Korea Institute of Geoscience and Mineral Resources in Daejeon, South Korea (Hong et al. 2010). The $\Delta^{14} \mathrm{C}$ values of samples were calculated with oxalic II and background samples older than 100,000 years, 


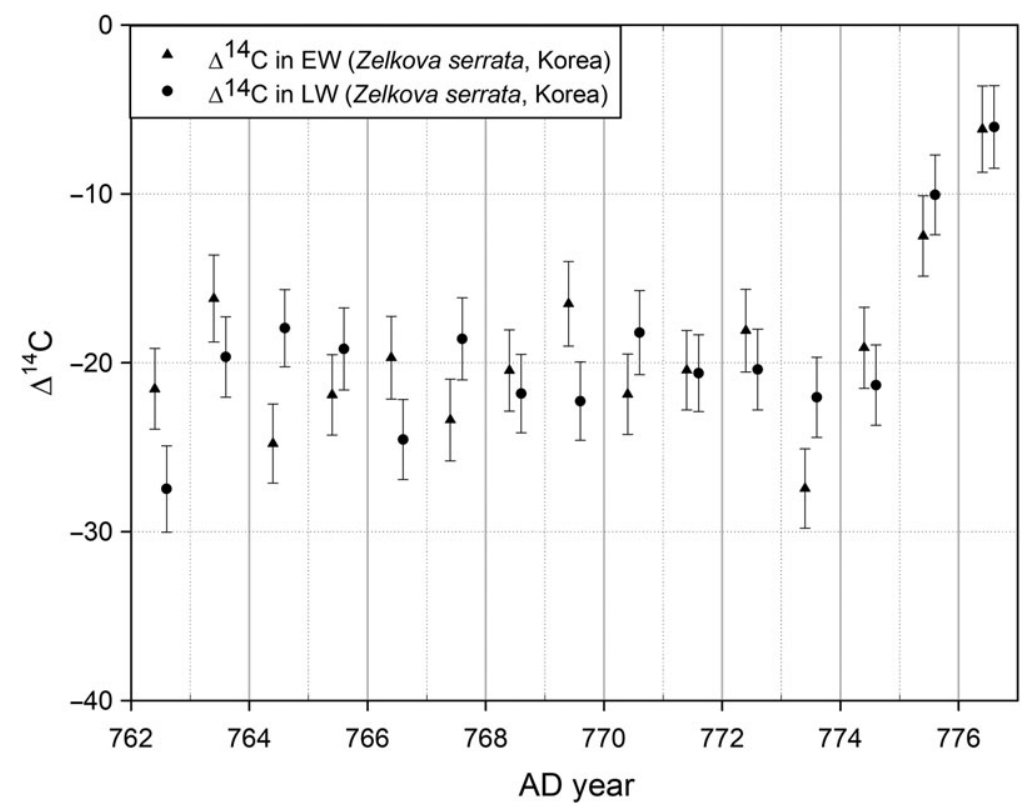

Figure $3 \quad \Delta^{14} \mathrm{C}$ of early- (solid triangles) and latewood (solid circles) in tree rings (Zelkova serrata) between AD 762 and AD 777 from Bangu-dong in Ulsan, Korea $\left(35^{\circ} 33^{\prime} \mathrm{N} 129^{\circ} 20^{\prime} \mathrm{E}\right)$.

which were measured together with unknown samples. To monitor the counting conditions, known samples (IAEA C7 and C8 reference materials) were measured approximately every 20 samples.

\section{RESULTS AND DISCUSSION}

Figure 3 shows the $\Delta^{14} \mathrm{C}$ values of the early- and latewood in tree rings between AD 762 and 776. The results confirm the existence of the M12 event and suggest that the height of M12 was approximately $15 \%$, which is consistent with the results of previous studies (Miyake et al. 2012; Uusitalo et al. 2018). No early rise in $\Delta^{14} \mathrm{C}$ in AD 774 early- or latewood was observed.

\section{Analysis of $\Delta{ }^{14} \mathrm{C}$ from AD 762-776 Early- and Latewood in South Korea}

A comparison of our results to those of previous studies (Miyake et al. 2012; Uusitalo et al. $2018)$ is shown in Figure 4. Although the results from Finland $\left(68.5^{\circ} \mathrm{N}, 28.1^{\circ} \mathrm{E}\right)$ show a significant early rise in the latewood of AD 774 (Uusitalo et al. 2018), our results did not identify an early rise in the early- or latewood of AD 774. This comparison shows that the height of the early rise in the latewood in AD 774 was dependent on latitude because the amplitude of M12 increased in accordance with an apparent increase in the latitude of the sampling site (Büntgen et al. 2018). In previous studies (Jull et al. 2014; Büntgen et al. 2018; Uusitalo et al. 2018), the early rise of $\Delta^{14} \mathrm{C}$ in AD 774 was observed at high latitudes in Russia $\left(67.5^{\circ} \mathrm{N}, 70.7^{\circ} \mathrm{E}\right)$ and Finland $\left(68.5^{\circ} \mathrm{N}, 28.1^{\circ} \mathrm{E}\right)$. 
Table 1 Estimates of the residence time of $\mathrm{CO}$ in the atmosphere.

\begin{tabular}{ll}
\hline Residence time & Reference \\
\hline 1 month & Brenninkmeijer et al. 1992 \\
0.1 year & Weinstock et al. 1969; Weinstock and Niki 1972 \\
2 months & Daniel 1999 \\
$2-5$ months & Volz et al. 1980 \\
$0.3-5$ years & Jaffe et al. 1968 \\
2 years & Logan et al. 1981 \\
5 years & Robbins et al. 1968 \\
\hline
\end{tabular}

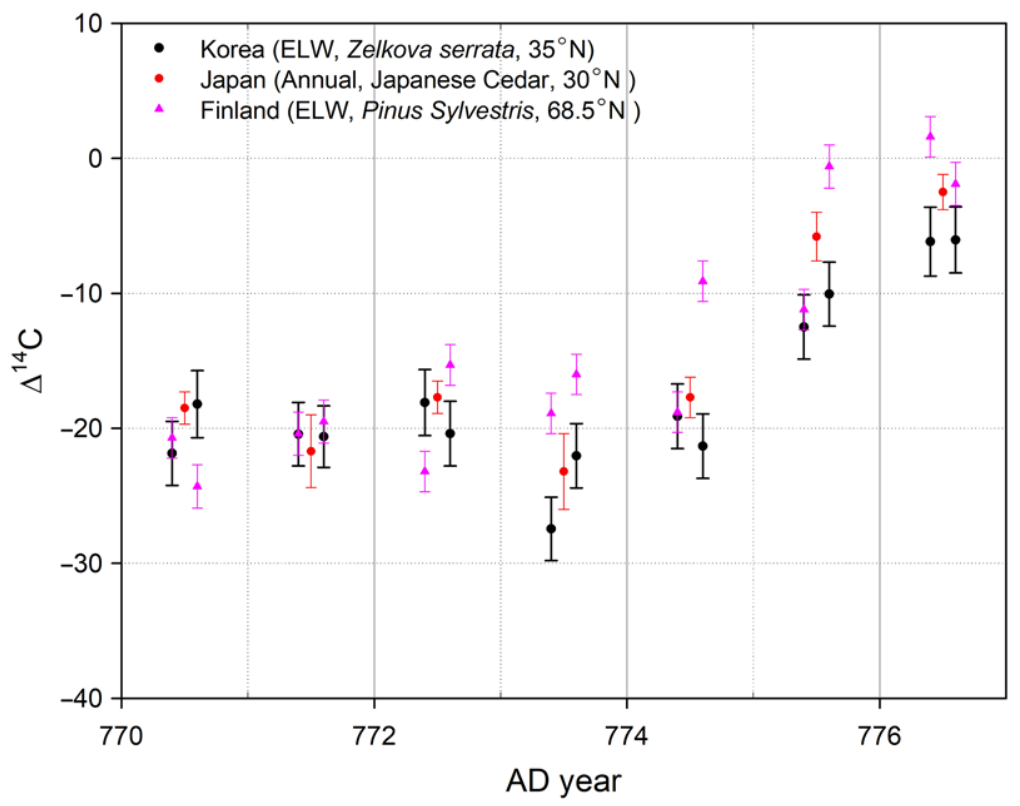

Figure 4 Results from other researchers (Miyake et al. 2012; Uusitalo et al. 2018) are compared with the present result (Korea, black solid circle). $\Delta^{14} \mathrm{C}$ of earlywood and latewood (Korea and Finland) were located in 0.4 and 0.6 of each year and $\Delta^{14} \mathrm{C}$ of annual tree ring (Japan, red solid circle) was located in 0.5 of each year. While the result from Finland (red solid triangle) shows a distinguished early rise in the latewood of $\mathrm{AD} 774$, this result does not show any early rise in early and latewood of $\mathrm{AD} 774$.

\section{Estimation of the Half-Oxidation Time (HOT) of ${ }^{14} \mathrm{C}$ Produced in the Troposphere}

Of the ${ }^{14} \mathrm{C}$ emitted by nuclear reactions, $95 \%$ is instantaneously oxidized into ${ }^{14} \mathrm{CO}$ (Pandow et al. 1960; MacKay et al. 1963; Jöckel et al. 2003). The residence time of CO in the atmosphere ranges approximately from 1 to 60 months, as shown in Table 1 (Jaffe et al. 1968; Robbins et al. 1968; Weinstock 1969; Weinstock and Niki 1972; Logan et al. 1981; Volz et al. 1980; Brenninkmeijer et al. 1992; Daniel 1999). The residence time of CO determined in studies from the 1990s, which are relatively recent, tended to be shorter, and CO levels are known to be affected by bacteria in soil (Duggin and Cataldo 1985). 


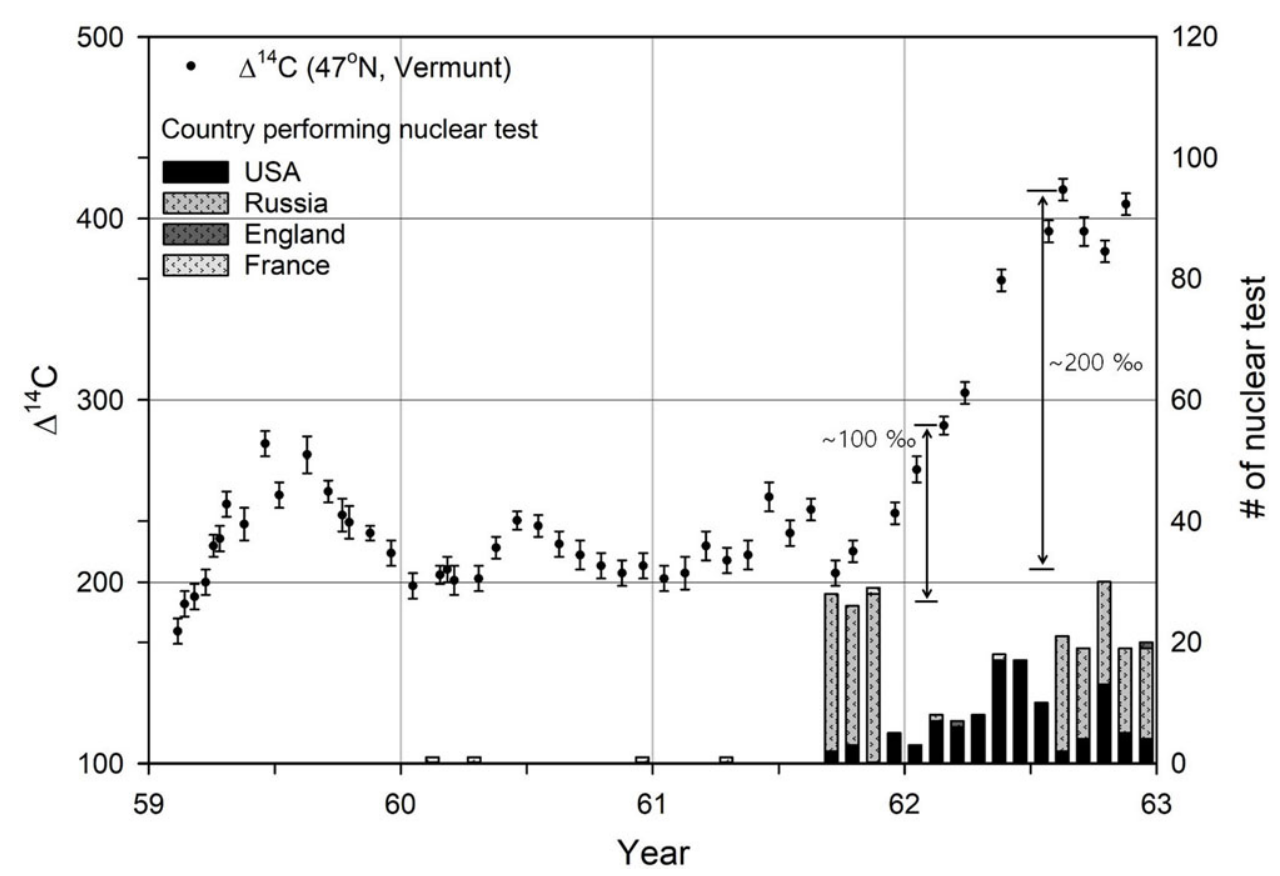

Figure 5 There is a small bomb peak from October in 1961 to February in 1962 (Levin et al. 1985), and this small bomb peak can be compared to the early rise in M12. The small bomb peak is composed of an initial increase of approximately 100\% from October 1961 to February 1962, followed by a second increase of approximately $100 \%$ from March to August 1962; the total height of this small bomb peak was approximately $200 \%$.

$\mathrm{CO}$ in the atmosphere is mainly oxidized into $\mathrm{CO}_{2}$, as follows (Volz et al. 1980):

$$
\mathrm{CO}+\mathrm{OH} \rightarrow \mathrm{CO}_{2}+\mathrm{H}
$$

The oxidation time of ${ }^{14} \mathrm{C}$ from nuclear reactions into ${ }^{14} \mathrm{CO}_{2}$ can be used to define the occurrence time of the ${ }^{14} \mathrm{C}$ spike using $\Delta^{14} \mathrm{C}$ values from tree rings. We attempted to calculate the oxidation time using peak ${ }^{14} \mathrm{C}$ from the bomb peak (Hua et al. 2013) because M12 can be considered similar to the increase in ${ }^{14} \mathrm{C}$ due to nuclear testing, or the "bomb peak." The bomb peak (main bomb peak) is a $\Delta^{14} \mathrm{C}$ peak that appeared in AD 1963 at Vermunt, Austria, as a result of nuclear waepon tests $\left(47^{\circ} \mathrm{N}\right.$, Levin et al. 1985), but Figures 5 and 6 show two small peaks that appeared in AD 1958 and AD 1962. The small bomb peak observed in August 1962 can be used to estimate the half-oxidation time (HOT) of ${ }^{14} \mathrm{C}$ in the troposphere. The small bomb peak is composed of an initial increase of approximately $100 \%$ from October 1961 to February 1962, followed by another increase of approximately 100\% from March to August 1962. The total height of this small bomb peak was approximately 200\%o (Figure 5). Nuclear test results from 1959 to 1963 are shown in Figure 5 (Johnston 2013). There were no nuclear tests by the Soviet Union or USA in 1959-1960. The Soviet Union conducted 74 nuclear tests above $48^{\circ} \mathrm{N}$ during September-November 1961, and the USA conducted 10 nuclear tests below $38^{\circ} \mathrm{N}$ during September-December 1961. This led to the conclusion that the initial increase in the small bomb peak measured at Vermunt, Austria, was mostly due to the Russian nuclear tests. From January to August 1962, the USA conducted 70 nuclear tests. However, the site of 


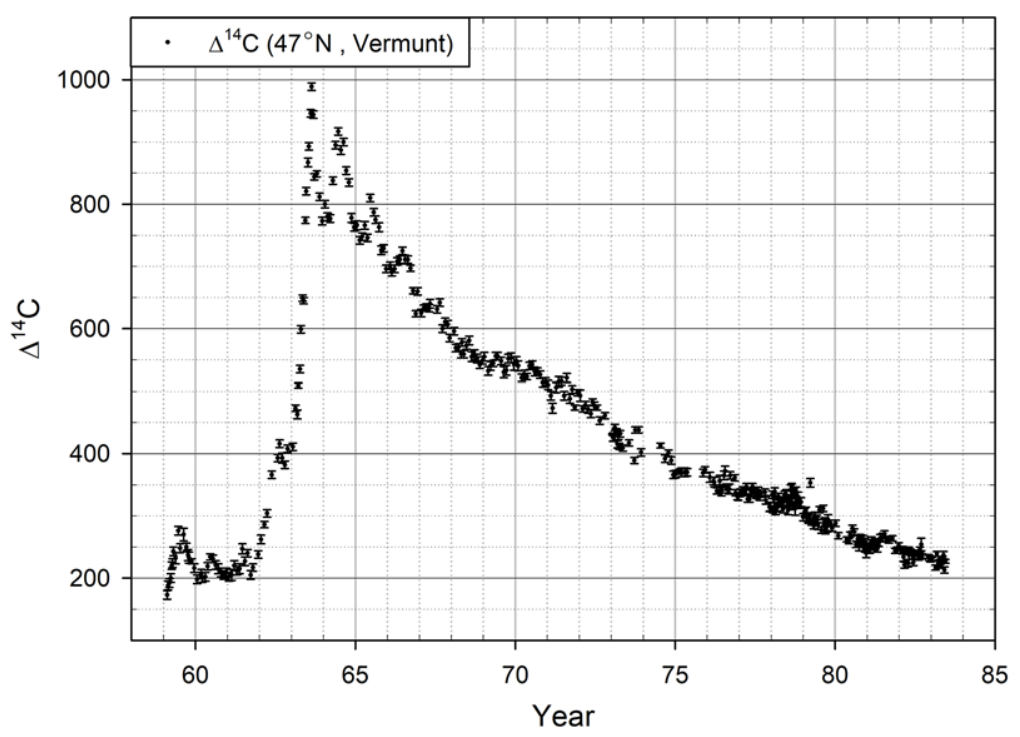

Figure $6 \quad \Delta^{14} \mathrm{C}$ in atmosphere at Vermunt (Levin et al. 1985). This bomb peak was produced by atmospheric nuclear tests.

the nuclear tests was situated far from Vermunt, and most of the tests occurred in May-July 1962, and thus were too close to August and too far from Vermunt to have caused the second increase in the small bomb peak.

The observed small bomb peak can be used to estimate the HOT of ${ }^{14} \mathrm{C}$ in the troposphere. There are two reasons for this. First, we assumed that the small bomb peak (October 1961 to February 1962) was only due to high-latitude nuclear tests in Russia; thus, the analysis and assumptions in the estimation of the HOT were relatively straightforward. Second, the initial increase in the small bomb peak occurred in autumn and winter, and was indicated by the ${ }^{14} \mathrm{C}$ produced in the troposphere due to short dispersion time and absence of a spring seasonal effect; i.e., we can exclude the Brewer-Dobson circulation ("spring mixing" from the stratosphere to the troposphere from May to June). The ${ }^{14} \mathrm{C}$ dispersion time at similar latitudes was therefore approximately 1-2 weeks, shorter than the HOT, which is known to range from 1 to 60 months (see Table 1). Hence, based on the small bomb peak, it is possible to estimate the HOT from a comparison between the initial increase with its small ratio of ${ }^{14} \mathrm{C}$ oxidation, and the second increase, with a large ratio of ${ }^{14} \mathrm{C}$ oxidation.

The height of the initial increase in the small bomb peak was estimated to be $100 \%$ in February 1962, as shown in Figure 5. The height of the initial increase was overestimated due to the seasonal decrease in $\Delta^{14} \mathrm{C}$, and this initial increase required 4 months, from the time of the Soviet tests in October 1961 (the middle of a 3-month period of nuclear tests in 1961 in Russia) to February 1962, for the $100 \%$ increase to be observed. The second increase in the small bomb peak (height of 200\%), from March to August 1962, matched the Brewer-Dobson circulation model and was similar to the bomb peaks in 1963, 1964, and 1965, as shown in Figure 6. The second increase occurred during the time of the normal Brewer-Dobson circulation model. The total ${ }^{14} \mathrm{C}$ produced by this small bomb peak could potentially increase $\Delta^{14} \mathrm{C}$ to $140 \%$ o $(70 \%$ of the total height [200\%] of the small bomb peak) for the entire Earth, similar to the main bomb peak (1000\%o at high latitudes and 
Table $2 \quad \Delta^{14} \mathrm{C}$ and ${ }^{14} \mathrm{C}$ amounts calculated based on the assumption of a linear increase with latitude according to Equation (3) and equalization of $\mathrm{C}_{\mathrm{sb}_{-} \mathrm{T}}$ with the sum presented below.

\begin{tabular}{lccr}
\hline $\begin{array}{l}\text { Area from pole to latitude } \\
\text { divided by } 10^{7}\left(\mathrm{~A}, \mathrm{~km}^{2}\right)\end{array}$ & Latitude $\left(^{\circ}\right)$ & $\Delta^{14} \mathrm{C}$ at latitude $(\%)$ & ${ }^{14} \mathrm{C}(\mathrm{kg})$ \\
\hline 1.00 & 73.9 & $4.49 \mathrm{E}+02$ & $9.01 \mathrm{E}+00$ \\
2.00 & 67.2 & $4.06 \mathrm{E}+02$ & $8.14 \mathrm{E}+00$ \\
3.00 & 61.9 & $3.62 \mathrm{E}+02$ & $7.27 \mathrm{E}+00$ \\
4.00 & 57.5 & $3.19 \mathrm{E}+02$ & $6.40 \mathrm{E}+00$ \\
5.00 & 53.5 & $2.76 \mathrm{E}+02$ & $5.53 \mathrm{E}+00$ \\
6.00 & 49.9 & $2.32 \mathrm{E}+02$ & $4.66 \mathrm{E}+00$ \\
$\mathbf{6 . 8 7}$ & $\mathbf{4 7}$ & $\mathbf{1 . 9 5 E}+\mathbf{0 2}$ & \\
7.00 & 46.5 & $1.89 \mathrm{E}+02$ & $3.79 \mathrm{E}+00$ \\
8.00 & 43.3 & $1.46 \mathrm{E}+02$ & $2.92 \mathrm{E}+00$ \\
9.00 & 40.3 & $1.02 \mathrm{E}+02$ & $2.05 \mathrm{E}+00$ \\
10.0 & 37.4 & $5.89 \mathrm{E}+01$ & $1.18 \mathrm{E}-01$ \\
11.0 & 34.7 & $1.56 \mathrm{E}+01$ & $3.12 \mathrm{E}-01$ \\
$\mathbf{1 1 . 4}$ & $\mathbf{3 3 . 7}$ & $-\mathbf{2 . 6 5 E}-\mathbf{0 2}$ & $-\mathbf{1 . 9 1 E}-\mathbf{0 3}$ \\
12.0 & 32.0 & $-2.78 \mathrm{E}+01$ & \\
& & Sum & 51 \\
\hline
\end{tabular}

$700 \%$ in the equatorial range, making the average $~ 700 \%$ ). The amount of ${ }^{14} \mathrm{C}$ corresponding to the initial increase in the small bomb peak due to tropospheric dispersion $\left(\mathrm{C}_{\mathrm{sb}-\mathrm{T}}\right)$ was obtained from the following equation, under the assumption that the ${ }^{14} \mathrm{C}$ production in the troposphere is $30 \%$ (Naegler and Levin 2006; Yang et al. 2000) of the total ${ }^{14} \mathrm{C}$ production (supplementary materials).

$$
\begin{gathered}
C_{s b_{-} T}=\frac{H_{s b_{-} e q}}{\left(1-e^{\left.\left(M_{s b} \times \ln 2\right) / T_{1 / 2}\right)}\right.} \times C \times T(30 \%)=51 \mathrm{~kg}, \\
C=\text { The amount of }{ }^{14} C / \%=\frac{1023 \mathrm{~kg}}{1000 \%}(\text { Schimel et al. 1996), }
\end{gathered}
$$

where $\mathrm{H}_{\text {sb_eq }}(140 \%$ ) represents $70 \%$ of the total height $(200 \%)$ of the small bomb peak. Similarly to the tendency of the main bomb peak, T $(30 \%)$ represents the amount of ${ }^{14} \mathrm{C}$ in the troposphere as a proportion of the total ${ }^{14} \mathrm{C}, \mathrm{M}_{\mathrm{sb}}(10$ months) represents the time required for the total increase in the small bomb peak to occur (October 1961 to August 1962), and $\mathrm{T}_{1 / 2}$ (3.8 months) represents the HOT of ${ }^{14} \mathrm{C}$.

It was assumed that the ${ }^{14} \mathrm{C}$ produced in the troposphere by nuclear tests was dispersed at $33.7^{\circ} \mathrm{N}$ (the lowest latitude of the ${ }^{14} \mathrm{C}$ dispersion area for 4 months based on the 1.5 years for which the bomb peak was dispersed throughout the Earth; supplementary materials) in February 1962. The amount of $\Delta^{14} \mathrm{C}$ then increased linearly with latitude (as shown in Equation [3] and Table 2), the amount of $\Delta^{14} \mathrm{C}$ could be obtained at each latitude, and the

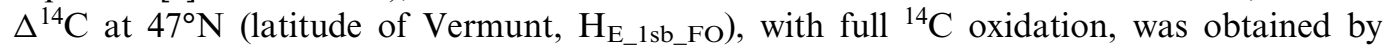
equalizing $\mathrm{C}_{\mathrm{sb} \_\mathrm{T}}$ (based on an assumption of almost complete ${ }^{14} \mathrm{C}$ oxidation) with the sum in Table 2 determined from the adjustment of $B$ and $C$ in Equation (3). The oxidation ratio of ${ }^{14} \mathrm{C}$ for 4 months was obtained using Equation (4) (supplementary materials). 
Table 3 HOTs were recalculated with variations of the ratio of ${ }^{14} \mathrm{C}$ production in the troposphere in the range $25-35 \%$. The $\mathrm{HOT}$ of ${ }^{14} \mathrm{C}$ was calculated to range from 2 to 7 months.

\begin{tabular}{lc}
\hline Ratio of ${ }^{14} \mathrm{C}$ produced & \\
in the troposphere $(\%)$ & HOT (months) \\
\hline 25 & 2.3 \\
30 & 3.8 \\
35 & 6.7 \\
\hline
\end{tabular}

$$
\Delta^{14} C=-B \times A+C,
$$

where $A$ represents the area from the pole to the specified latitude divided by $10^{7}$, and $B(=492.3)$ and $C(=43.3)$ are obtained from adjusting to equalize $\mathrm{C}_{\mathrm{sb}_{-} \mathrm{T}}$ with the sum of ${ }^{14} \mathrm{C}$ in Table 2 (supplementary materials).

* $\mathrm{H}_{\mathrm{E} \_1 \text { sb_FO }}$

$$
\frac{H_{1 s b}}{H_{E \_1 s b \_F O}} \sim 51 \%={ }^{14} C_{-} O x_{-} r\left({ }^{14} \mathrm{C} \text { oxidation ratio for } 4 \text { months }\right),
$$

where $\mathrm{H}_{1 \mathrm{sb}}\left(100 \%\right.$ ) represents the $\Delta^{14} \mathrm{C}$ height of the first increase in the small bomb peak (from October 1961 to February 1962), and $\mathrm{H}_{\mathrm{E}}$ 1sb FO represents the $\Delta^{14} \mathrm{C}$ height of the first increase in the small bomb peak with ${ }^{14} \mathrm{C}$ full oxidation.

The HOT of ${ }^{14} \mathrm{C}$ was calculated as approximately 3.8 months using iterations of Equation (5) and the calculation procedure presented in the supplementary materials:

$$
\left.\frac{T_{1 s b} * L N(2)}{L N\left(1-{ }^{14} C_{-} O x_{-} r\right)}=T_{1 / 2} \text { (half oxidation time of }{ }^{14} C\right) \text {, }
$$

where $\mathrm{T}_{1 \mathrm{sb}}$ (4 months) represents the duration of the first increase in the small bomb peak, and ${ }^{14} \mathrm{C} \_\mathrm{Ox} \_r(51 \%)$ represents the ${ }^{14} \mathrm{C}$ oxidation ratio for $\mathrm{T}_{1 \mathrm{sb}}(4$ months).

Among the assumptions used during calculation of the HOT, the ratio of ${ }^{14} \mathrm{C}$ production in the troposphere is sensitive to the value of HOT, so HOTs were recalculated while varying the ratios in the range of $25-35 \%$, as shown in Table 3 . HOTs were obtained in the range of 2-7 months and were estimated to be in the range of 1-7 months considering the recalculation and a relatively recent report by Bernninkmeijer et al. (1992).

It can be assumed that the ${ }^{14} \mathrm{C}$ produced in the troposphere in AD 774 was dispersed to $49.1^{\circ} \mathrm{N}$, which is the latitude of the average area between the Finnish and South Korean sampling locations. Given that there was no early rise in $\Delta^{14} \mathrm{C}$ in the latewood of AD 774 in South Korea, as opposed to in Finland, it can also be assumed that $\Delta^{14} \mathrm{C}$ increased linearly with latitude. Based on the HOT of 3.8 months and the above assumptions, $\Delta^{14} \mathrm{C}$ at the sampling location $\left(68.5^{\circ} \mathrm{N}\right)$ in Finland (Figure 7) can be calculated by equalizing the sum of ${ }^{14} \mathrm{C}$ amounts of the latitudes with $\mathrm{OR}_{-}{ }^{14} \mathrm{CO}_{2}$ of Equation (6), similar to obtaining $\mathrm{H}_{\mathrm{E}}$ 1sb FO (supplementary materials). The calculated $\Delta{ }^{14} \mathrm{C}$ result, shown in Figure 7 , can be checked against the " ${ }^{14} \mathrm{C}$ spike production time" sheet in the supplementary materials. 
Table 4 Increases in $\Delta^{14} \mathrm{C}$ of earlywood (EW) and latewood (LW) in AD 774 (Uusitalo et al. 2018) were estimated. The increases in the $\Delta^{14} \mathrm{C}$ of $\mathrm{EW}$ and LW in AD 774 were calculated from the difference between the $\Delta^{14} \mathrm{C}$ values of $\mathrm{EW}$ and $\mathrm{LW}$ in $\mathrm{AD} 774$ and the average $\Delta^{14} \mathrm{C}$ values of EW and LW from AD 770-773.

\begin{tabular}{lccc}
\hline & $\begin{array}{c}\Delta^{14} \mathrm{C} \text { in AD } 774 \\
(\%, \mathrm{~A})\end{array}$ & $\begin{array}{c}\text { Average } \Delta^{14} \mathrm{C} \text { in } \mathrm{AD} \\
770-773(\%, \mathrm{~B})\end{array}$ & $\begin{array}{c}\text { Increase in } \Delta^{14} \mathrm{C} \\
(\mathrm{A}-\mathrm{B}, \%)\end{array}$ \\
\hline Latewood $(\mathrm{LW})$ & $-9.1 \pm 1.5$ & $-18.8 \pm 4.1$ & $9.7 \pm 2.2$ \\
Earlywood (EW) & $-18.8 \pm 1.5$ & $-20.8 \pm 1.8$ & $2.0 \pm 1.2$ \\
\hline
\end{tabular}

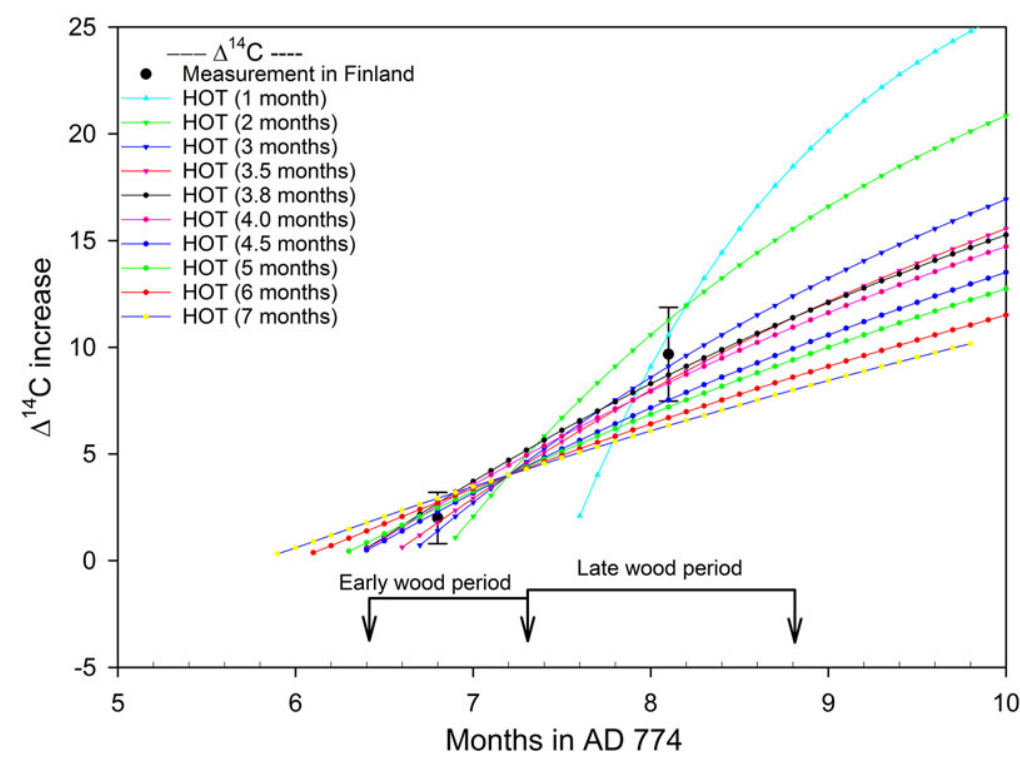

Figure 7 Comparison of $\Delta{ }^{14} \mathrm{C}$ measured in Finland with $\Delta{ }^{14} \mathrm{C}\left({ }^{(" 14} \mathrm{C}\right.$ spike production time" sheet in the supplementary materials) calculated according to various HOTs.

$$
\text { OR }{ }_{-}^{14} \mathrm{CO}_{2}={ }^{14} C_{M 12} \times \text { Tropos_ratio } \times\left(1-\exp \left(-(T \times L N(2)) / T_{1 / 2}\right)\right)
$$

where ${ }^{14} C_{M 12}$ represents the total ${ }^{14} \mathrm{C}$ produced in $\mathrm{M} 12$, Trospos_ratio $(30 \%)$ represents the proportion of ${ }^{14} \mathrm{C}$ produced in the troposphere, and $T$ represents the time after the abrupt increase in the production of ${ }^{14} \mathrm{C}$.

\section{Estimation of Time of ${ }^{14} \mathrm{C}$ Spike Production}

As shown in Table 4, which gives the $\Delta^{14} \mathrm{C}$ results of Finnish wood, the $\Delta^{14} \mathrm{C}$ increase in earlywood in AD 774 was $2.0 \pm 1.2$, and that of latewood was $9.7 \pm 2.2$ (Uusitalo et al. 2018). The $\Delta^{14} \mathrm{C}$ increase of earlywood in $\mathrm{AD} 774$ was calculated from the difference between the amount of ${ }^{14} \mathrm{C}$ in earlywood in $\mathrm{AD} 774$ and the average ${ }^{14} \mathrm{C}$ of earlywood from $\mathrm{AD} 770$ to 773 , whereas the $\Delta^{14} \mathrm{C}$ increase of latewood in $\mathrm{AD} 774$ was calculated from the difference between the amount of ${ }^{14} \mathrm{C}$ in latewood in $\mathrm{AD} 774$ and the average $\Delta^{14} \mathrm{C}$ of latewood from AD 770-773. 
The onset date of cambium division and the length of the growing season vary from year to year as well as over a longer scale because tree phenology and climate variability (temperature) influence cell production and the calendar dates of early- and latewood formation. However, the tree ring width (TRW) of 2000-year tree rings does not show summer temperatures in Finland (Esper et al. 2012) or certain other trends. Thus, although estimation from cambium division and xylem formation can still result in errors due to phenology and climate variability, we can attempt to estimate the onset times of early- and latewood, as well as the end time of latewood, of a Scots pine tree from AD 775 based on their times in recent Scots pine trees. The onset time of the earlywood of a Scots pine tree used for the measurement of M12 was June $11 \pm 5$; the onset time of latewood was July $10 \pm 5$, and the end time of latewood was August $26 \pm 9$ (Seo et al. 2010, 2011; Cuny et al. 2015; supplementary materials). The onset time of earlywood of the Scots pine tree was defined as the onset time of the radial growth of earlywood; the onset time of latewood was defined as the onset time of the radial growth of latewood (Seo et al. 2010, 2011). However, the end time of latewood was defined as the sum of the end time of the radial growth of latewood and the time lag ( 27 days) between the woody biomass production and xylem size increase (radial growth) in the boreal region, as woody biomass production proceeds after the end time of the xylem size increase (Seo et al. 2010, 2011; Cuny et al. 2015).

The time required for trees to absorb $\mathrm{CO}_{2}$ from the air via photosynthesis and produce tree ring tissue via metabolism is approximately one month (Grootes et al. 1989). Air mixing and the oxidation of ${ }^{14} \mathrm{C}$ in the troposphere occur simultaneously; however, the oxidation of ${ }^{14} \mathrm{C}$ proceeds at a significantly slower rate. Although the rate of air mixing between different latitudes is slower, the air mixing times at the sampling location in Finland and similar latitudes were considered negligible due to westerly winds. The $\Delta^{14} \mathrm{C}$ in the early- and latewood periods in Finland (Figure 7) noted in the preceding paragraph were calculated under the assumptions of a linear increase in $\Delta^{14} \mathrm{C}$ with an increase in latitude (supplementary materials), HOT, and a one-month delay between photosynthesis and metabolism. The Volz et al. 1980; $\chi^{2}$ values were obtained from the difference (divided by measurement error) between the $\Delta^{14} \mathrm{C}$ values of early- and latewood in Finland and the calculated $\Delta^{14} \mathrm{C}$ values.

$$
\chi^{2}=\left(\Delta^{14} C_{m}-\Delta^{14} C_{c}\right)_{E}^{2} / \sigma_{m, E}^{2}+\left(\Delta^{14} C_{m}-\Delta^{14} C_{m}\right)_{L}^{2} / \sigma_{m, L}^{2}
$$

where $\mathrm{m}$ represents a $\Delta^{14} \mathrm{C}$ measurement in Finland, c represents a $\Delta^{14} \mathrm{C}$ calculation, $\sigma$ represents the error of $\Delta^{14} \mathrm{C}$ measurements in Finland, E represents early wood, and $\mathrm{L}$ represents late wood.

The occurrence time of the abrupt increase in ${ }^{14} \mathrm{C}$ production was approximately mid-May (5.3 months) from a minimum $\chi^{2}$ value of 0.56 . Although the occurrence time of the ${ }^{14} \mathrm{C}$ spike obtained by Güttler et al. (2015) was between September AD 774 and September AD 775, and that by Büntgen et al. (2018) was between June and August of AD 774, the calculation in this study yielded an occurrence time of approximately mid-May (5.3 months) in AD 774, i.e., a few months earlier than the estimation by Büntgen. This difference can be attributed to the consideration of the oxidation times of ${ }^{14} \mathrm{C}$ in this study.

The value of HOT can vary from 1 to 6 months due to variation in the amount of ${ }^{14} \mathrm{C}$ produced in the troposphere. The month of the abrupt increase in ${ }^{14} \mathrm{C}$ with the lowest $\chi^{2}$ value for each HOT is presented in Table 5. This result indicates that the occurrence time of the abrupt increase in production of ${ }^{14} \mathrm{C}$ was from late April to mid-June in AD 774. This is still a few 
Table 5 According to variations in HOT, the month of the abrupt increase in ${ }^{14} \mathrm{C}$ with the lowest value of $\chi^{2}$ for each HOT is presented.

\begin{tabular}{lcc}
\hline HOT (months) & Best fit month & $\chi^{2}$ \\
\hline 1 (Bernninkmeijer et al. 1992) & 6.5 & 2.95 \\
2 (Daniel 1999) & 5.8 & 0.47 \\
3 & 5.6 & 0.10 \\
3.5 & 5.5 & 0.44 \\
3.8 & 5.3 & 0.56 \\
4.0 & 5.3 & 0.63 \\
4.5 & 5.3 & 1.07 \\
5.0 & 5.2 & 1.48 \\
\hline
\end{tabular}

months earlier than the estimation by Büntgen (Büntgen et al. 2018) and 10 months earlier than that made by Güttler (Güttler et al. 2015). These differences are mainly due to the lack of consideration of ${ }^{14} \mathrm{C}$ oxidation time.

\section{CONCLUSION}

We measured $\Delta^{14} \mathrm{C}$ values for the early- and latewood tree rings of Zelkova serrata from AD 762-776 at Bangu-dong, Ulsan, South Korea, confirming the presence of M12 in a South Korean tree.

A comparison of the results obtained in this study and those from previous studies suggests that, in addition to the latitude dependence of the highest $\Delta^{14} \mathrm{C}$ values of M12 (Büntgen et al. 2018), the height of the early rise in $\Delta^{14} \mathrm{C}$ in $\mathrm{AD} 774$ also varied according to latitude; we did not see an identifiable early rise in $\Delta^{14} \mathrm{C}$ in either the early- or latewood of AD 774 in South Korea, whereas a notable early rise in $\Delta^{14} \mathrm{C}$ in the latewood of AD 774 was observed at high latitudes (Finland).

The HOT of ${ }^{14} \mathrm{C}$ produced in the air could be estimated by a detailed analysis of a small bomb peak from October AD 1961 to August AD 1962. The HOT of ${ }^{14} \mathrm{C}$ was calculated to range from 2 to 7 months, based on analysis of a small bomb peak similar to M12 for the calculation of HOT, whereas the residence time of $\mathrm{CO}$ was estimated from sources and sinks of $\mathrm{CO}$, although the residence time of $\mathrm{CO}$ and HOT were almost the same. From the estimated values of HOT, including another recent estimate ( 1 month, Brenninkmeijer et al. 1992; Daniel 1999), and a comparison of $\Delta^{14} \mathrm{C}$ values calculated and measured in the early- and latewood periods in Finland, the occurrence time of the abrupt increase in ${ }^{14} \mathrm{C}$ production was estimated to have occurred sometime during the period of late April to mid-June in AD 774.

\section{ACKNOWLEDGMENTS}

This research was supported by the Basic Research Project of the Korea Institute of Geoscience and Mineral Resources (KIGAM), funded by the Ministry of Science and ICT of South Korea. The English in this document has been checked by at least two professional editors, both native English speakers. For a certificate, please see: http://www.textcheck.com/certificate/L6W55i. 


\section{SUPPLEMENTARY MATERIAL}

To view supplementary material for this article, please visit https://doi.org/10.1017/RDC. 2020.69

\section{REFERENCES}

Baker JCA, Hunt SFP, Clerici SJ, et al. 2015. Oxygen isotopes in tree rings show good coherence between species and site in Bolivia. Global and Planetary Change 133:298-308.

Bétrisey S, Song Y, Kozlowski G. 2018. Zelkova serrata. The IUCN Red List of Threatened Species 2018: e.T61967528A61967548.

Brenninkmeijer CAM, Manning MR, et al. 1992. Interhemispheric asymmetry in $\mathrm{OH}$ abundance inferred from measurements of atmospheric ${ }^{14}$ CO. Nature 356(5):50-52

Büntgen U, Lukas W, et al. 2018. Tree rings reveal globally coherent signature of cosmogenic radiocarbon events in 774 and 993 CE. Nature Communications (2018) 9:3605. doi: 10.1038/ s41467-018-06036-0.

Choi E-B. 2019. Comparisons between tree-ring $\delta^{18} \mathrm{O}$ and ring-width chronologies-Based on synchronizations among intra- and inter- species and between provinces [master's thesis]. Chungbuk National University, Cheongju, Republic of Korea. p. 57-58.

Cuny HE, Rathgeber CBK, Frank D, Fonti P, et al. 2015. Woody biomass production lags stem-girth increase by over one month in coniferous forest. Nature plants. Vol. 1. doi: 10.1038/nplants.2015.160.

Daniel JJ. 1999. Introduction to atmospheric chemistry. Chapter 11. Princeton University Press. p. 199-219.

Dee M, Pope B, Miles D, Manning S, Miyake F. 2017. Supernovae and single-year anomalies in the atmospheric radiocarbon record. Radiocarbon 59(2):293-302.

Duggin JA, Cataldo DA. 1985. The rapid oxidation of atmospheric $\mathrm{CO}$ to $\mathrm{CO}_{2}$ by soils. Soil Biology and Biochemistry 17(4): 469-474.

Esper J, Frank DC, et al. 2012 Orbital forcing of tree-ring data. Nature Climate Change. Vol. 2. doi: 10.1038/NCLIMATE1589.

Gehrels N, Laird CM, Jackman CH, et al. 2003. Ozone depletion from nearby supernovae. The Astrophysical Journal 585:1169-1176.

Grootes PM, Farwell GW, Schmidi FH, Leach DD, Stuiver M. 1989. Importance of biospheric $\mathrm{CO}_{2}$ in a subcanopy atmosphere deduced from ${ }^{14} \mathrm{C}$ AMS measurements. Radiocarbon 31(3):475-480.

Güttler D, Adolphi F, Beer J, et al. 2015. Rapid increase in cosmogenic ${ }^{14} \mathrm{C}$ in AD 775 measured in New Zealand kauri trees indicates short-lived increase in ${ }^{14} \mathrm{C}$ production spanning both hemispheres. Earth and Planetary Science Letters 411:290-297.
Hambaryan VV, Neuhäuser R. 2013. Galactic short gamma-ray burst as cause for the ${ }^{14} \mathrm{C}$ peak in AD 774/5. Monthly Notices of the Royal Astronomical Society 430:32-36.

Hong W, Park JH, Sung KS, Woo HJ, Kim JK, Choi HW, Kim GD. 2010. A new 1MV AMS facility at KIGAM. Radiocarbon 52(2-3):243-251.

Hua Q, Barbetti M, Zoppi U, et al. 2004. Radiocarbon in tropical tree rings during the little ice age. Nuclear Instruments and Methods in Physics Research B 223-224:489-494

Hua Q, Barbetti M, Rakowski AZ. 2013. Atmospheric radiocarbon for the period 19502010. Radiocarbon 55(4):2059-2072.

Jaffe LS. 1968. Ambient carbon monoxide and its fate in the atmosphere. Journal of the Air Pollution Control Association 18(8):534.

Johnston WM. 2013. Johnston Archive of Nuclear Weapons. http://www.johnstonsarchive.net/nuclear/.

Jöckel P, Brenninkmeijer CAM, Lawrence MG, Siegmund P. 2003. The detection of solar proton produced ${ }^{14} \mathrm{CO}$. Atmospheric Chemistry and Physics 3:999-1005.

Jull AJT, Panyushkina IP, Lange TE, et al. 2014. Excursions in the ${ }^{14} \mathrm{C}$ record at $\mathrm{AD} 774-775$ in tree rings from Russia and America. Geophysical Research Letters 41. doi: 10.1002/ 2014 GL059874.

Levin I, Kromer B, Schoch-Fischer H, Bruns M, et al. 1985. 25 years of tropospheric ${ }^{14} \mathrm{C}$ observations in central Europe. Radiocarbon 27(1):1-19.

Li Z, Nakatsuka T, Sano M. 2015. Tree-ring cellulose $\delta^{18} \mathrm{O}$ variability in pine and oak and its potential to reconstruct precipitation and relative humidity in central Japan. Geochemical Journal 49(2):125-137.

Logan JA, Prather MJ, et al. 1981. Tropospheric chemistry: a global perspective. Journal of Geophysical Research 86(C8):7210.

Mackay C, Pandow M, Wolfgang R. 1963. On the chemistry of natural radiocarbon. Journal of Geophysical Research 68(13): 3929.

Mekhaldi F, Muscheler R, Adolphi F, et al. 2015. Multi-radionuclide evidence for the solar origin of the cosmic-ray events of AD 774/5 and 993/ 4. Nature Communications 6:8611. doi: 10. 1038/ncomms9611.

Melott AL, Thomas BC. 2012. Causes of an AD $774-775{ }^{14} \mathrm{C}$ increase. Nature 491:E1-E2.

Miyake F, Nagaya K, Masuda K, Nakamura T. 2012. A signature of cosmic-ray increase in AD 774-775 from tree rings in Japan. Nature 486:240-242. 
Miyake F, Masuda K, Nakamura T. 2013. Another rapid event in the carbon-14 content of tree rings. Nature Communications 4:1748. doi: 10 . 1038/ncomms 2783 .

Naegler T, Levin I. 2006. Closing the global radiocarbon budget 1945-2005. Journal of Geophysical Research 111, D12311. doi: 10. 1029/2005JD006758.

Neuhäuser R, Neuhäuser DL. 2015. Variations of ${ }^{14} \mathrm{C}$ around $\mathrm{AD} 775$ and $\mathrm{AD} 1795$-due to solar activity. Astronomische Nachrichten AN336(10): 930-954.

Pandow M, MacKay C, Wolfgang R. 1960. The reaction of atomic carbon with oxygen: significance for the natural radiocarbon cycle. Journal of Inorganic and Nuclear Chemistry 14:153-158.

Park JH, Southon J, Fahrni S, Creasman PP, Mewaldt R. 2017. Relationship between solar activity and $\Delta^{14} \mathrm{C}$ peaks in AD 775, AD 994, and 660 BC. Radiocarbon 59(4):1147-1156.

Pavlov AK, Blinov AV, Konstantinov AN, et al. 2013. AD 775 pulse of cosmogenic radionuclides production as imprint of a galactic gamma-ray burst. Monthly Notices of the Royal Astronomical Society 435:2878-2884.

Robbins RC, Borg KM, Robinson E. 1968. Carbon monoxide in the atmosphere. Journal of the Air Pollution Control Association 18(2):106-110.

Schimel D, et al. 1996. Radiative forcing of climate change. In: Houghton JT et al., editors. Climate change 1995: the science of climate change. Cambridge: Cambridge University Press.

Seo JW, Salminen H, Jalkanen R, and Eckstein D. 2010. Chronological coherence between intraannual height and radial growth of Scots pine (Pinus sylvestris L.) in the northern boreal zone of Finland. Baltic Forestry 16(1):57-65.

Seo JW, Eckstein D, Jalkanen R, and Schmitt U. 2011. Climatic control of intra- and inter-annual wood-formation dynamics of Scots pine in northern Finland. Environmental and Experimental Botany 72:422-431.

Seo JW, Jeong HM, Sano M, et al. 2017. Establishing tree ring $\mathrm{d}^{18} \mathrm{O}$ chronologies for principle tree species (T. cuspidate, P. koraiensis, A. koreana, Q. mongolica) at subalpine zone in Mt. Jiri National Park and their correlations with the corresponding climate. Journal of the Korean Wood Science and Technology 45(5):661-670.

Stephenson FR. 2015. Astronomical evidence relating to the observed ${ }^{14} \mathrm{C}$ increases in A.D. $774-5$ and 993-4 as determined from tree rings. Advances in Space Research 55:1537-1545.

Thomas BC, Melott AL, Arkenberg KR, and Snyder II BR. 2013. Terrestrial effects of possible astrophysical sources of an AD 774-775 increase in ${ }^{14} \mathrm{C}$ production. Geophysical Research Letters 40:1237-1240.

Usoskin IG, Kromer B, Ludlow F, et al. 2013. The AD775 cosmic event revisited: the Sun is to blame. Astronomy \& Astrophysics 552, L3. doi: 10.1051/0004-6361/201321080.

Uusitalo J, Arppe L, Hackman T, Helama S, et al. 2018. Solar superstorm of AD 774 recorded subannually by Arctic tree rings. Nature Communications 9:3495. doi: 10.1038/s41467018-05883-1.

Volz A, Tönnissen A, Ehhalt DH and Khedim A. 1980. OH radicals via atmospheric ${ }^{14} \mathrm{CO}$. Radiocarbon 22(2):372-378.

Weinstock B. 1969. Carbon monoxide: residence time in the atmosphere. Science 166:224-225.

Weinstock B, Niki H. 1972. Carbon monoxide balance in nature. Science 176:290-292.

Yang X, North R, Romney C. 2000. CMR nuclear explosion database (revision 3), CMR Tech. Rep. 00/16, Cent. for Monitor. Res., U.S. Army Space and Missile Defense Command, Arlington, VA. 